\title{
PENGARUH MODEL PEMBELAJARAN BERBASIS MASALAH BERBANTUAN SIMULATION BASED LABORATORY (SBL) TERHADAP HASIL BELAJAR FISIKA PESERTA DIDIK KELAS XI IPA SMAN 1 MONTONG GADING
}

\author{
Nurhikmah*, Gunawan, Syahrial Ayub \\ Program Studi Pendidikan Fisika, Universitas Mataram \\ *Email: hikmah.fisika12@yahoo.com
}

\begin{abstract}
This research is aimed to know the influence of Problem-Based Learning Models assisted with Simulation Based Laboratory (SBL) on students' physics learning outcome in class XI IPA of SMAN 1 Montong Gading academic year 2015/2016. The material used in the research is momentum and impulses. The type of the research is quasi experiment with pretest-posttest control group design. The population which is used in this research are the whole students of class XI IPA of SMAN 1 Montong Gading which decided by purposive sampling technique. C lass XI IPA 1 as the experiment class and class XI IPA 2 as the control class. The result of study was analized using t-test polled varians. Based on the research outcome, it can be concluded that Problem-Based Learning Models Assisted with Simulation Based Laboratory (SBL) influenced students`physics learning outcome.
\end{abstract}

Keywords: Problem-Based Learning, Simulation Based Laboratory (SBL), Learning outcome

\section{PENDAHULUAN}

Pada hakikatnya Ilmu Pengetahuan Alam (IPA) merupakan suatu produk, proses, dan sikap. Fisika merupakan bagian dari IPA maka dapat diambil persepsi bahwa hakikat fisika sama dengan hakikat IPA. Pada hakikatnya, IPA mencakup proses, produk, dan sikap. Sebagai proses, IPA fokus pada bagaimana cara mendapatkan ilmu pengetahuan seangkan sebagai produk sebagai produk, IPA lebih menekankan pada apa yang dihasilkan dalam IPA itu sendiri (Gunawan et al., 2017). Hasil-hasil penemuan dari berbagai kegiatan penyelidikan dikumpulkan dan disusun secara sistematik menjadi sebuah kumpulan pengetahuan yang disebut sebagai produk. Kumpulan pengetahuan itu dapat berupa fakta, konsep, prinsip, hukum, rumus, teori, atau model. Pemahaman fisika sebagai suatu proses adalah pemahaman mengenai bagaimana informasi ilmiah dalam fisika diperoleh, diuji, dan divalidasikan. Proses penemuan, pengamatan, pengukuran, dan penyelidikan ilmiah yang dilakukan memerlukan proses mental dan sikap yang berasal dari pemikiran yang tercermin dalam rasa ingin mengetahui dan rasa penasaran mereka yang besar, diiringi dengan rasa percaya, sikap objektif, jujur, dan terbuka, serta mau mendengarkan pendapat orang lain. Sikapsikap itulah yang kemudian memaknai hakekat fisika sebagai sikap (Hikmawati \& Gunada, 2013).

Fisika adalah salah satu cabang ilmu pengetahuan yang terus mengalami perkembangan. Seiring dengan perkembangannya, masalah-masalah dalam pembelajaran fisika dicari solusi dan perbaikannya. Salah satu diantara masalah tersebut yakni terkait dengan pembelajaran fisika di kelas. Masalah yang sering disoroti adalah rendahnya pemahaman peserta didik pada materi fisika yang diajarkan. Dalam proses belajar mengajar, banyak faktor yang terlibat di dalamnya baik dari peserta didik yang belajar maupun guru yang mengajar. Faktor yang berasal dari peserta didik sendiri adalah bahan pelajaran, ketekunan, keuletan, kerajinan, dan kedisiplinan dalam belajar. Sedangkan faktor dari guru adalah 
materi pelajaran dan model pembelajaran yang digunakan.

Fisika sebagai produk, proses, dan sikap dalam pembelajarannya harus mempertimbangkan metode pembelajaran yang efektif dan efisien karna fisika adalah salah satu cabang ilmu IPA yang menutut peserta didik untuk mampu memecahkan masalah. Dewasa ini peserta didik lebih cenderung mempelajari bagaimana cara menyelesaikan soal-soal hitungan yang diberikan guru namun lemah pada pemahaman konsep pada saat diberikan masalah untuk dianalisis jadi sangat dibutuhkan model pembelajaran yang menuntut peserta didik memecahkan masalah. Berdasarkan hasil observasi yang dilakukan di SMA Negeri 1 Montong Gading pada kelas XI IPA dapat disimpulkan hasil belajar fisika yang rendah disebabkan oleh tidak tertariknya peserta didik terhadap materi yang diajarkan. Sebagian besar peserta didik menganggap pelajaran fisika sebagai mata pelajaran yang membosankan, karena setiap kali pertemuan selalu diberikan tugas dan pekerjaan rumah. Banyak peserta didik tidak berminat terhadap pelajaran fisika dikarenakan mereka menganggap pelajaran fisika adalah materi yang sangat sulit dipahami, selain itu mereka dituntut untuk menghapal persaman - persamaan fisika sehingga mereka mampu menyelesaikan soal yang diberikan saat ujian atau penugasan. Peserta didik lebih cenderung menghapal dibandingkan dengan menganalisis masalah. Sehingga apabila peserta didik diberikan masalah yang lebih menekankan analisis mereka akan kesulitan dalam pemecahannya. Oleh karena itu dibutuhkan model pembelajaran yang menuntut peserta didik untuk aktif dalam memecahkan masalah.

Ada beberapa model pembelajaran yang menuntut peserta didik untuk aktif untuk menemukan suatu informasi melalui proses berfikir ilmiah diantaranya adalah model pembelajaran berbasisis masalah. Model pembelajaran berbasis masalah didefinisikan sebagai rangkaian aktivitas pembelajaran yang menekankan pada proses penyelesaian masalah secara ilmiah. Model pembelajaran berbasis masalah mengusung gagasan utama bahwa tujuan pembelajaran dapat tercapai jika kegiatan pendidikan dipusatkan pada tugas-tugas atau permasalahan yang autentik, relevan, dan dipresentasikan dalam suatu konteks. Masalah yang dikemukakan kepada siswa harus dapat membangkitkan pemahaman siswa terhadap masalah, kesadaran adanya kesenjangan, pengetahuan, tujuan keinginan memecahkan masalah, dan persepsi bahwa mereka mampu memecahkan masalah tersebut Pembelajaran berbasis masalah memberikan kesempatan kepada siswa untuk mengumpulkan dan menganalisis data secara lengkap dalam memecahkan masalah yang dihadapi. Karenanya, siswa dapat membangun sendiri konsep yang dipelajarinya, serta dapat mengembangkan keterampilan berpikirnya dalam memecahkan masalah. Fokus model pembelajaran ini adalah penyelesaian masalah terkait materi pembelajaran, bukan bagaimana guru menyampaikan materi pembelajaran. Dalam pembelajaran berbasis masalah, siswa bekerjasama dalam kelompok sehingga terjadi pertukaran pikiran yang dapat membangun penyelesaian masalah (Huda, 2013).

Selain model pembelajaran, hal lain yang mempengaruhi hasil belajar siswa adalah media pembelajaran. Robert Heinich (2005) menyatakan tentang media yaitu,"media is means of communication and source of information". Jadi media merupakan segala sesuatu yang dapat digunakan sebagai sumber informasi dan komunikasi.Dalam pembelajaran media 
memegang peranan yang sangat penting dan sebagai salah satu faktor yang mempengaruhi kualitas keberhasilan pembelajaran. Seiring dengan perkembangan zaman dan kemajuan teknologi, saat ini banyak terdapat media yang dapat dimanfaatkan dalam proses pembelajaran, salah satunya adalah media komputer. Media komputer ini dapat dapat digunakan sebagai salah satu media yang inovatif dan interaktif dalam pembelajaran fisika. Melalui media komputer dapat ditampilkan konsep-konsep Fisika baik berupa animasi simulasi, video, dan sebagainya yang dapat mempermudah siswa untuk menemukan dan mengkonstruksi konsep dalam belajar. Penggunaan media komputer dalam pelaksanaannya belum dapat dimaksimalkan di kelas, meskipun saat ini hampir semua institusi pendidikan termasuk sekolah memiliki fasilitas komputer yang cukup baik. Komputer sebagai alat bantu pembelajaran hanya menjadi media pengganti papan tulis, belum dimaksimalkan fungsinya untuk membangun konsep siswa khususnya dalam pembelajaran Fisika (Herayanti \& Habibi 2015). Penggunaan media pembelajaran harus disesuaikan dengan pendekatan metode yang digunakan. Media pembelajaran Fisika berbasis komputer yang sesuai dengan model pembelajaran berbasis masalah yaitu Simulation Based Laboratory (SBL) merupakan simulasi laboratorium yang berisi percobaan Fisika yang dapat dikontrol variabel - variabelnya.

Model pembelajaran berbasis masalah berbantuan Simulation Based Laboratory $(S B L)$ menjadi salah satu solusi alternative dalam proses pembelajaran di kelas. Dengan menggunakan model dan media pembelajaran yang efektif memberikan kesempatan kepada peserta didik untuk mengembangkan sejumlah keterampilan dan meningkatkan kualitas belajar sehingga diharapkan hasil belajarnya akan meningkat.

\section{METODE PENELITIAN}

Jenis penelitian yang digunakan adalah penelitian quasi eksperimen dengan desain untreated control group design with pretest and postest. Sebelum diberi perlakukan kedua kelompok sampel diberikan tes awal untuk mengukur kondisi awal. Selanjutnya kelas eksperimen diberikan perlakuan dengan menggunakan model pembelajaran berbasisis masalah berbantuan simulation based laboratory $(S B L)$ dan kelas kontrol diberi perlakuan berupa model pembelajaran konvensional (direct instruction). Sesudah perlakuan, kedua kelas diberikan tes akhir.

Dalam penelitian ini ada 3 variabel yaitu variabel bebas yaitu strategi model pembelajaran berbasisis masalah berbantuan simulation based laboratory $(S B L)$,variabel terikat yaitu hasil belajar fisika pada materi momentum dan impuls, variable kontrol yaitu materi ajar yang diajarkan, guru yang mengajar, dan instrumen penilaian pada kelas eksperimen dan kontrol. Populasi dalam penelitian ini adalah seluruh siswa kelas XI IPA di SMAN 1 Montong gading tahun ajaran 2015/2016. Sedangkan sampel adalah bagian dari populasi. Sampel yang digunakan dipilih dengan menggunakan teknik purposive random sampling. Penelitian ini, untuk mengukur hasil belajar digunakan tes berupa pilihan ganda sebanyak 25 soal. Sebelumnya tes pilihan ganda di uji validitasnya sehingga diperoleh 26 soal yang valid. Uji F digunakan untuk mengetahui homogenitas data dan uji normalitas untuk mengetahui apakah data terdistribusi normal atau tidak. Setelah itu, untuk mengetahui peningkatan nilai kedua 
tes ebelum dan sesudah diberi perlakuan digunakan uji t polled varians.

\section{HASIL DAN PEMBAHASAN}

Berdasarkan ranah yang dinilai, yaitu ranah kognitif, maka kemampuan yang diukur adalah kemampuan kognitif hasil belajar. Tes yang diberikan adalah tes tertulis berbentuk pilihan ganda yang terdiri dari 25 soal.Adapun hasil belajar siswa sebelum diberikan perlakuan terlihat dari nilai tes awalnya (pre-test), dan hasil belajar setelah diberikan perlakuan terlihat dari nilai tes akhir (pos-test).

Tes awal dilakukan untuk mengetahui homogenitas serta normalitas sampel sebelum diberikan perlakuan. Tes akhir dilakukan setelah kedua kelas diberikan perlakuan menggunakan model pembelajaran berbasisis masalah berbantuan simulation based laboratory $(S B L)$. Nilai rata-rata tes awal dan tes akhir kelas eksperimen dan kelas kontrol dapat dilihat pada Gambar 1.

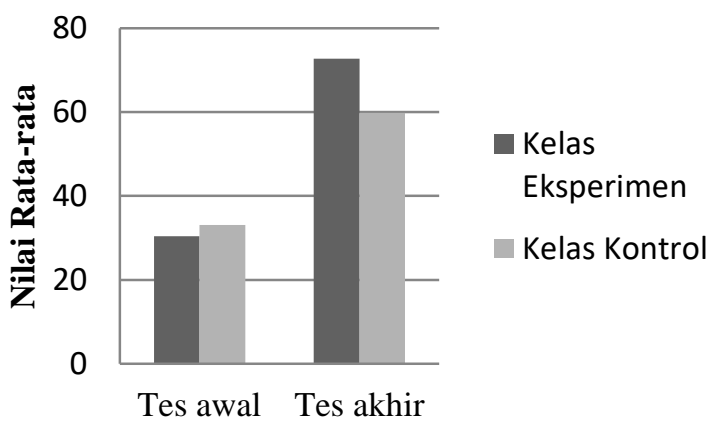

Gambar 1. Perbandingan Nilai Rata-rata Tes awal dan Tes akhir

Berdasarkan Gambar 1 di atas, pada tes awal nilai rata- rata kelas kontrol lebih tinggi dibandingkan dengan kelas eksperimen, dan pada tes akhir dapat terlihat bahwa nilai rata-rata kelas eksperimen lebih tinggi dibandingkan kelas kontrol. Pada nilai rata-rata tes awal kelas eksperimen dan kontrol yakni 30,42 dan 33,07 dengan selisih rata-rata 2,65. Sedangkan nilai rata-rata tes akhir kelas eksperimen dan kontrol yakni 72,75 dan 59,80 dengan selisih 12,92.

Pengujian data hasil belajar siswa untuk kelas eksperimen dan kelas kontrol tes awal dan tes akhir diawali dengan uji homogenitas kedua data, yang dilanjutkan dengan uji normalitas, dan terakhir uji hipotesis menggunakan uji-t polled varians. Dari uji homogenitas data untuk tes awal yang telah dilakukan didapat hasil $F_{\text {hitung }}<$ $F_{\text {tabel }}$ yang berarti data tes awal kedua kelas adalah homogen (Arikunto, 2012).

Selanjutnya dilakukan uji normalitas data tes awal dan tes akhir pada masingmasing kelas. Berdasarkan perhitungan yang telah dlakukan didapatkan hasil bahwa data berdistribusi normal pada tes awal dan tes akhir untuk kelas eksperimen dan kelas kontrol. Untuk tes akhir didapatkan nilai $\chi_{\text {hitung }}^{2}<\chi_{\text {tabel }}^{2}$ yang berarti data tes akhir untuk kedua kelas terdistribusi normal (Ariknto, 2010).

Untuk mengetahui adanya pengaruh model pembelajaran berbasis masalah berbantuan simulation based laboratory $(S B L)$ dalam meningkatkan hasil belajar siswa dilakukan uji hipotesis. Uji hipotesis menggunakan statistik parametrik karena data homogen dan terdistribusi normal. Uji hipotesis yang digunakan adalah uji t-test polled varians. Berdasarkan hasil perhitungan didapatkan $t_{\text {hitung }}>t_{\text {tabel }}$ yaitu 6,52 $>2,00$ pada taraf signifikan $5 \%$ dengan derajat kebebasan $(\mathrm{dk})=\mathrm{n}_{1}+\mathrm{n}_{2}-2$ $=28+30-2=56$. Sesuai dengan kriteria pengujian hipotesis yaitu $t_{\text {hitung }}>t_{\text {tabel }}$ maka $\mathrm{H}_{0}$ ditolak $\mathrm{H}_{\mathrm{a}}$ diterima. Dengan demikian, dari hasil penelitian dapat disimpulkan bahwa pembelajaran berbasis masalah berbantuan Simulation Based Laboratory (SBL) berpengaruh terhadap hasil belajar fisika peserta didik. Hal ini berarti terdapat pengaruh yang signifikan, yang berarti perlakuan yang diberikan 
mempunyai pengaruh terhadap kelompok eksperimen.

Peningkatan hasil belajar kelas eksperimen yang diberikan perlakuan dengan menerapkan model pembelajaran berbasis masalah berbantuan Simulation Based Laboratory (SBL) mengalami peningkatan yang lebih besar karena kegiatan pembelajaran menggunakan model pembelajaran berbasis masalah berbantuan Simulation Based Laboratory (SBL) menuntut peserta didik untuk terlibat aktif dalam proses pembelajaran. Meskipun media ini tidak memberikan pengalaman langsung kepada peserta didik karena tidak menggunakan alat-alat yang konkrit, namun penggunaan media virtual simulasi lebih mampu meningkatkan pemahaman peserta didik. Selama kegiatan pembelajaran berlangsung, peserta didik dapat mengamati kesesuaian antara hipotesis dengan fakta yang terjadi terkait eksperimen yang sedang dilaksanakan. Apabila hipotesis yang dibuat peserta didik terkait masalah sudah sesuai dengan fakta yang terjadi selama proses eksperimen, maka hal ini dapat memperkuat pemahaman peserta didik mengenai materi yang sedang dipelajari. Sebaliknya, apabila hipotesis yang dibuat oleh peserta didik belum sesuai dengan fakta yang terjadi selama proses eksperimen menggunakan Simulation Based Laboratory (SBL), maka hal ini dapat memberikan pemahaman yang benar kepada peserta didik. Pemahaman yang diperoleh melalui kegiatan eksperimen menggunakan Simulation Based Laboratory $(S B L)$ ini dapat membangun pengetahuan peserta didik, karena peserta didik secara aktif terlibat dalam pembelajaran untuk memecahkan masalah dengan mengumpulkan data dan fakta. Data yang diperoleh peserta didik melalui kegiatan eksperimen menggunakan Simulation Based Laboratory (SBL) selanjutnya digunakan untuk menjawab pertanyaan- pertanyaan yang telah tersedia dalam Lembar Kegiatan Peserta Didik (LKPD). Terkait pertanyaan ini, peserta didik dituntut untuk berdiskusi dengan anggota kelompok masing-masing untuk mencari jawaban berdasarkan data yang diperoleh, sehingga peserta didik dapat bertukar informasi mengenai jawaban yang paling benar untuk setiap pertanyaan. Kemudian hasil eksperimen dan diskusi disampaikan oleh salah satu kelompok di depan kelas dan ditanggapi oleh kelompok lain. Penyampaian hasil eksperimen ini memberikan kesempatan kepada peserta didik untuk saling bertukar informasi antar kelompok. Selain itu, kekurangan masingmasing kelompok terkait materi momentum dan impuls dapat diketahui, sehingga pada akhir presentasi didapatkan kesimpulan akhir yang benar dan sama pada setiap kelompok. Oleh karena itu, peserta didik mendapatkan pengetahuan yang sama terkait masalah yang disajikan di awal pembelajaran, sehingga peserta didik dapat menjawab permasalah tersebut. Berdasarkan hal tersebut dapat disimpulkan dengan adanya perubahan pada hasil belajar fisika memperlihatkan bahwa penerapan model pembelajaran berbasis masalah berbantuan Simulation Based Laboratory $(S B L)$ di kelas eksperimen memberikan pengaruh positif terhadap hasil belajar fisika peserta didik. Hal ini menunjukan bahwa kelas eksperimen yang diberikan perlakuan berupa pembelajaran berbasis masalah berbantuan Simulation Based Laboratory (SBL) terhadap hasil belajar fisika peserta didik lebih tinggi dari pada kelas kontrol. Hal ini karena, pembelajaran berbasis masalah berbantuan Simulation Based Laboratory (SBL) memberikan kesempatan kepada peserta didik untuk menyelesaikan suatu permasalahan melalui proses berpikir ilmiah. Menurut Rusman (2010), masalah dapat mendorong 
keseriusan inquiri (keingintahuan). Keingintahuan pada suatu masalah ini difasilitasi dengan simulasi berbasis komputer. Hasil dalam penelitian ini juga semakin menguatkan teori bahwa melalui pembelajaran berbasis masalah peserta didik tidak hanya memahami konsep yang relevan dengan masalah yang menjadi pusat perhatian, tetapi juga memperoleh pengalaman belajar yang berhubungan dengan keterampilan menerapkan metode ilmiah dalam pemecahan masalah. Menurut Jauhari, et al., (2016), model pembelajaran berbasis masalah berbantuan media simulasi dapat mengaktifkan peserta didik melalui kegiatan pemecahan masalah. Hal ini dapat dilihat dari aktivitas dan antusias peserta didik dalam menjalani proses pembelajaran, sehingga berdampak terhadap hasil belajar fisika kelas eksperimen lebih baik dibandingkan kelas kontrol. Menurut Wahyuni \& Widiarti (2010) Pengalaman dalam memecahkan masalah memberikan kesempatan kepada peserta didik untuk bertukar pikiran dengan anggota kelompoknya, mengembangkan kemampuan berpikir berdasarkan masalah, dan membangun pengetahuannya sendiri.

Hal ini sesuai dengan teori yang menyatakan bahwa pembelajaran berbasis masalah memberikan kesempatan kepada peserta didik untuk belajar berfikir kritis dan memperoleh kemampuan memecahkan masalah yang dihadapai. Selain itu penggunaan Simulation Based Laboratory (SBL) dalam proses pemecahan masalah memberikan kesempatan kepada peserta didik untuk mencari dan menemukan sendiri berbagai jawaban atas persoalanpersoalan yang dihadapinya dengan mengadakan percoabaan sendiri melalui cara berpikir yang ilmiah menggunakan Simulation Based Laboratory (SBL). Hal ini sesuai dengan pendapat Huda (2013) bahwa, pembelajaran berbasis masalah memberikan kesempatan kepada peserta didik untuk mengumpulkan dan menganalisis data secara lengkap dalam memecahkan masalah yang dihadapai. Karenanya, dapat membangun sendiri konsep yang dipelajarinya, serta dapat mengembangkan keterampilan berpikirnya berdasarkan pemecahan masalah. Fokus model pembelajaran ini adalah penyelesaian masalah terkait materi pembelajaran, bukan bagaimana guru menyampaikan materi pembelajaran. Dalam pembelajaran berbasis masalah, peserta didik bekerjasama dalam kelompok sehingga terjadi pertukaran pikiran yang dapat membangun penyelesaian masalah. Selain itu, menurut Abidin (2014), model pembelajaran berbasis masalah dengan metode eksperimen menyediakan pengalaman autentik yang mendorong peserta didik untuk belajar aktif, mengkonstruksi pengetahuan, dan mengintegrasi konteks belajar di sekolah dan belajar di kehidupan nyata secara ilmiah. Keterampilan menerapkan metode ilmiah inilah yang menuntun peserta didik melatih keterampilan proses sainsnya (Susanto, et al. 2015). Selain model pembelajaran, Finkelstein, dkk. (2004) telah melakukan pengujian efek simulasi komputer sebagai pengganti laboratorium nyata dalam pembelajaran Fisika di kelas dan memperoleh hasil peserta didik yang diajar melalui simulasi mendapatkan hasil belajar yang luar biasa dibandingkan dengan peserta didik yang diajar menggunakan laboratorium nyata. Dengan demikian, peserta didik dapat memperolah dan mengkonstruksi pengetahuannya melalui keterpaduan kegiatan kajian teoritik dan eksperimen. Penggunaan media ini dalam pembelajaran Fisika sangat membantu peserta didik dalam belajar.

\section{PENUTUP}


Berdasarkan hasil dan pembahasan yang telah dipaparkan dapat disimpulkan bahwa model pembelajaran model pembelajaran berbasis masalah berbantuan simulation based laboratory ( $\mathrm{sbl}$ ) berpengaruh terhadap hasil belajar fisika peserta didik kelas XI SMAN 1 Montong Gading tahun pelajaran 2015/2016). Adapun saran yang dapat diberikan bagi guru fisika model pembelajaran model pembelajaran berbasis masalah berbantuan simulation based laboratory ( $S B L$ ) yang dapat diterapkan dalam mengajar fisika. Namun, dalam penerapannya memerlukan perencanaan dan persiapan yang matang sebelum diterapkan di kelas agar proses pembelajaran dapat berjalan sesuai dengan tujuan pembelajaran yang ingin dicapai. Sedangkan untuk penelitian selanjutnya, model pembelajaran model pembelajaran berbasis masalah berbantuan simulation based laboratory (SBL) dapat dilakukan pada materi yang berbeda dengan subjek peneliitian yang lebih luas.

\section{REFERENSI}

Abidin, Y. 2014. Desain Sistem Pembelajaran Dalam Konteks Kurikulum 2013. Bandung: PT Refika Adiatama.

Arikunto, S. 2010. Prosedur Penelitian. Jakarta: Rineka Cipta.

2012. Dasar-dasar Evaluasi Pendidikan Edisi Revisi. Jakarta: Bumi Aksara.

Fahrizal, E., Sar, S. \& Parmi, S. 2013. Problem Based Learning Dalam Pembelajaran Fisika Menggunakan Simulation Based Laboratory (SBL) Dan Video Based Laboratory (VBL). Jurnal materi dan pembelajaran Fisika, 2, 25-36.

Gunawan, G., Sahidu, H., Harjono, A., \& Suranti, N. M. Y. The Effect of Project Based Learning with Virtual Media Assistance on Student's
Creativity in Physics. Cakrawala Pendidikan, (2), 167-179.

Herayanti, L, \& Habibi. 2015. Model Pembelajaran Berbasis masalah Berbantuan Simulasi Komputer untuk Meningkatkan Keterampilan Berfikir Kritis Calon Guru Fisika”. Jurnal pendidikan Fisika dan Teknologi, 1(1), 61-66.

Heinich, Robert. 2005. Instructional Technology and Media for Learning. Ohio: Merill Prentice Hall.

Hikmawati, \& Gunada, I. W. 2013. Kajian Fisika SMA. Mataram: FKIP Universitas Mataram.

Huda, M. 2013. Model-Model Pengajaran dan Pembelajaran Isu-isu Metodis dan Pragmatis. Yogyakarta: Pustaka Pelajar.

Jauhari, T., Hikmawati, \& Wahyudi. 2016. Pengaruh Model Pembelajaran Berbasis Masalah Berbantuan Media Phet Terhadap Hasil Belajar Fisika Peserta didik Kelas X SMAN 1 Gunungsari Tahun Pelajaran 2015/2016. Jurnal Pendidikan Fisika dan Teknologi, 2(1), 7-12.

Rusman. 2010. Model-model Pembelajaran Mengembangan Profesionalisme Guru. Jakarta: PT Rajagrafindo Persada

2015. Statistika untuk Penelitian. Bandung: Alfabeta.

Susanto, D., Sutrio \& Wahyudi 2015. Pengaruh Pembelajaran Berbasis Masalah Melalui Metode Eksperimen Terhadap Keterampilan Proses Sains Fisika Peserta didik SMA Negeri 1 Selong Tahun Ajaran 2014/2015. Jurnal Pendidikan Fisika dan Teknologi, 1(3), 160-165.

Wahyuni, S \& Widiarti, N. 2010. Penerapan Pembelajaran Berbasis Masalah Berorientasi ChemoEntrepreneurship Pada Praktikum Kimia Fisika. Jurnal Inovasi Pendidikan Kimia, 4(1), 484-496. 